\title{
Perkembangan Prinsip Tanggung Jawab (Bases Of Liability) dalam Hukum Internasional dan Implikasinya terhadap Kegiatan Keruangangkasaan
}

\author{
Neni Ruhaeni \\ Fakultas Hukum Universitas Islam Bandung \\ Jl. Rangga Gading No.8 Bandung \\ nenihayat@gmail.com
}

\begin{abstract}
This research discusses the development of bases of liability in international laws and its implications to any outer space activities. The research method was normative-juridical. The findings show that: first, based on the development history, there are three bases of liability in international laws; each has its own characters and implementation mechanisms. Second, the important implications of the development of bases of liability in international laws of outer space activities are written in Article II and Article III Liability Convention 1972 which are the elaboration of the stipulations in Article VII of the Outer Space Treaty 1967. As a consequence of Indonesian's participation in international outer space laws, bases of liability which is mentioned in Article II and Article III Liability Convention 1972 should be implemented in national legislation related to the liability in any outer space actitivies in Indonesia.
\end{abstract}

Keywords: Bases of liability, international liability, outer space activities

\begin{abstract}
Abstrak
Penelitian ini mengkaji tentang perkembangan prinsip tanggung jawab (bases of liability) dalam hukum internasional dan bagaimana implikasinya terhadap kegiatan keruangangkasaan. Metode penelitian yang digunakan dalam penelitian ini adalah yuridis normatif. Penelitian ini menyimpulkan: pertama, berdasarkan sejarah perkembangannya, dalam hukum internasional berlaku tiga bases of liability yang masing-masing memiliki karakter dan mekanisme penerapan yang berbeda. Kedua, implikasi penting dari perkembangan bases of liability dalam hukum internasional terhadap kegiatan keruangangkasaan tersurat dalam Article II dan Article III Liability Convention 1972 yang merupakan elaborasi dari ketentuan Article VII the Outer Space Treaty 1967. Selanjutnya, sebagai konsekuensi dari keikutsertaan Indonesia dalam instrumen-instrumen hukum ruang angkasa internasional, bases of liability yang ditetapkan dalam Article II dan Article III Liability Convention 1972 semestinya dapat diaplikasikan dalam legislasi nasional tentang tanggung jawab dalam kegiatan keruangangkasaan di Indonesia.
\end{abstract}

Kata Kunci: Prinsip tanggung jawab, tanggung jawab internasional, kegiatan keruangangkasaan 


\section{Pendahuluan}

Konsep tanggung jawab internasional dalam hukum ruang angkasa pada mulanya diperkenalkan dalam Resolusi Majelis Umum PBB 1962 tentang prinsipprinsip yang mengatur kegiatan negara-negara dalam eksplorasi dan penggunaan ruang angkasa, ${ }^{1}$ khususnya prinsip kelima dan kedelapan. Berdasarkan kedua prinsip tersebut, negara-negara bertanggung jawab secara internasional untuk kegiatan eksplorasi dan pemanfaatan ruang angkasa ${ }^{2}$ nasionalnya, baik yang dilakukan oleh badan pemerintah maupun oleh entitas non-pemerintah. Berdasarkan kedua prinsip ini pula, negara harus menjamin kegiatan keruangangkasaan yang dilakukan di negaranya sesuai dengan prinsip-prinsip yang tercantum dalam Deklarasi. Selanjutnya, setiap negara yang meluncurkan atau menyelenggarakan peluncuran suatu obyek ke ruang angkasa, dan setiap negara yang menyediakan wilayahnya atau memfasilitasi peluncuran, bertanggung jawab secara internasional terhadap kerugian yang menimpa negara lain atau orang (secara natural atau secara yuridis) di negara lain yang diakibatkan oleh obyek tersebut atau sebagian komponen obyek tersebut yang terjadi baik di permukaan bumi, di ruang udara, atau di ruang angkasa. ${ }^{3}$ Prinsip kelima dan kedelapan Deklarasi tersebut kemudian diambil alih oleh the Outer Space Treaty 1967 (the OST) dan empat instrumen hukum ruang angkasa lainnya yang termasuk dalam corpus juris spatialis. ${ }^{4}$ Substansi ketentuan yang terdapat dalam Article VI dan Article VII the OST menetapkan bahwa negara merupakan aktor utama dalam kegiatan keruangangkasaan dan bahwa negara bertanggung jawab terhadap kegiatan keruangangkasaan nasionalnya baik yang dilakukan oleh badan

${ }^{1}$ The United Nations General Assembly Resolution 1962 (XVIII) of 13 December 1963 on Principles Governing the Activities of States in the Exploration and Use of Outer Space.

2 Untuk selanjutnya kegiatan eksplorasi dan pemanfaatan ruang angkasa disebut kegiatan keruangangkasaan.

${ }^{3}$ Lihat Declaration of Legal Principles Governing the Activities of States in the Exploration and Use of Outer Space, Prinsip Kelima dan Prinsip Kedelapan, United Nations Treaties and Principles on Outer Space, hlm. 47.

${ }^{4}$ Instrumen Hukum Ruang Angkasa yang terdiri dari 5(lima) perjanjian internasional yang mengatur kegiatan keruangangkasaan dikenal dengan istilah the Corpus Juris Spatialis. Kelima instrumen hukum ruang angkasa tersebut adalah: Treaty on Principles Governing the Activities of States in the Exploration and Use of Outer Space, including the Moon and Other Celestial Bodies, 1967 (the Outer Space Treaty/the OST); Agreement on the Rescue of Astronauts, the Return of Astronauts and the Return of Objects Launched into Outer Space, 1968 (the Rescue Agreement); Convention on International Liability for Damage Caused by Space Objects, 1972 (the Liability Convention); Convention on Registration of Objects Launched into Outer Space, 1975 (the Registration Convention); and Agreement Governing the Activities of States on the Moon and Other Celestial Bodies, 1979 (the Moon Treaty). 
pemerintah (governmental agencies) maupun yang dilakukan oleh entitas nonpemerintah (non-governmental entities).

Konsep tanggung jawab internasional atas kerugian yang diakibatkan oleh suatu kegiatan keruangangkasaan dalam instrumen hukum ruang angkasa diformulasikan melalui dua terminologi yang berbeda, yaitu responsibility dan liability. Perbedaan pengertian antara istilah responsibility dan liability seringkali menimbulkan perdebatan. Sebenarnya istilah responsibility dan liability mengandung pengertian yang sama dengan konotasi yang berbeda. Meskipun responsibility memiliki konsep yang lebih luas daripada liability, keduanya seringkali digunakan secara bergantian. Article VI the OST menggunakan istilah international responsibility, sementara Article VII the OST beserta pasal-pasal penjabarannya dalam Liability Convention 1972 menggunakan istilah international liability. Keterkaitan antara kedua pasal tersebut dapat dipahami sebagai kebebasan bagi "non-governmental entities" dan tanggung jawab bagi "state parties". Dengan demikian, teks yang tersurat dalam Article VI harus dibaca oleh negara-negara peserta the OST mengandung pengertian bahwa ketika suatu entitas non-pemerintah meluncurkan suatu obyek ruang angkasa, maka negara yang memberikan ijin melakukan kegiatan tersebut akan memikul tanggung jawab apabila kegiatan tersebut menimbulkan kerugian. Oleh karena itu, walaupun tidak bersifat wajib, setiap negara peserta the OST perlu membuat perundang-undangan nasional yang mengatur kegiatan keruangangkasaan di negaranya. Sehubungan negara Indonesia sampai saat ini belum memiliki peraturan perundang-undangan nasional yang mengatur tanggung jawab negara dalam kegiatan keruangangkasaan baik dalam arti responsibility maupun liability, sementara kegiatan keruangangkasaan di Indonesia sudah melibatkan nongovernmental entities sebagai aktor kegiatan keruangangkasaan, maka tanggung jawab sebagai suatu konsep hukum sangat penting untuk dikaji.

\section{Rumusan Masalah}

Masalah pokok yang akan dikaji dalam penelitian ini adalah: pertama, bagaimanakah perkembangan bases of liability dalam hukum internasional? Kedua, 
bagaimanakah implikasi perkembangan bases of liability dalam hukum internasional terhadap kegiatan keruangangkasaan?

\section{Tujuan Penelitian}

Target khusus dari penelitian ini adalah menemukan bentuk dan prinsip tanggung jawab yang paling tepat dalam kegiatan keruangangkasaan di Indonesia. Secara umum penelitian ini bertujuan untuk mengetahui, pertama, perkembangan bases of liability dalam hukum internasional. Kedua, implikasi perkembangan bases of liability dalam hukum internasional terhadap kegiatan keruangangkasaan.

\section{Metode Penelitian}

Penelitian ini menggunakan pendekatan yuridis normatif yaitu penelitian hukum yang meletakkan hukum sebagai sebuah bangunan sistem norma. ${ }^{5}$ Pada penelitian hukum jenis ini seringkali hukum dikonsepkan sebagai apa yang tertulis dalam peraturan perundang-undangan (law in books) atau hukum dikonsepkan sebagai kaidah atau norma yang merupakan patokan berperilaku manusia yang dianggap pantas, ${ }^{6}$ sehingga penelitian hukum normatif menjadikan sistem norma sebagai pusat kajiannya. Penelitian dilakukan dengan mendasarkan kepada bahan kepustakaan atau data sekunder. ${ }^{7}$ Data sekunder yang digunakan terdiri dari bahan hukum primer, yaitu konvensi-konvensi internasional, peraturan perundang-undangan nasional, putusan-putusan hakim, dan perangkat hukum lainnya yang berkaitan dengan topik penelitian ini. Bahan hukum sekunder yang digunakan adalah berbagai literatur dan pendapat pakar hukum yang berkaitan dan relevan dengan topik penelitian ini, baik berbentuk buku, jurnal, rancangan undang-undang, maupun hasil penelitian.

\footnotetext{
${ }^{5}$ Mukti Fajar dan Yulianto Achmad, Dualisme Penelitian Hukum Normatif dan Empiris, Pustaka Pelajar, Yogyakarta, 2010, hlm 34.

${ }^{6}$ Amirudin dan Zainal Asikin, Pengantar Metode Penelitian Hukum, Rajawali Press, Jakarta, 2010, hlm 118.

7 Pada penelitian hukum normatif yang diteliti hanya bahan pustaka atau data sekunder. Lihat Soerjono Soekanto, Pengantar Penelitian Hukum, UI-Press, 2008, hlm 52. Ronny Hanitijo Soemitro, Metodologi Penelitian Hukum dan Jurimetri, Ghalia Indonesia, Jakarta, 1990, hlm 11.
} 
Pengumpulan data sekunder dalam pelaksanaan penelitian ini dilakukan dengan studi kepustakaan terhadap bahan-bahan hukum, baik bahan hukum primer, bahan hukum sekunder, maupun bahan hukum tersier dan atau bahan non hukum. Diskusi melalui seminar/workshop perlu dilakukan untuk memperoleh bahan-bahan yang mendukung studi data sekunder. Analisis data dilakukan secara kualitatif yaitu dengan melakukan analisis kritis terhadap ketentuan yang berlaku dan fakta yang tersedia. Sifat analisis adalah deskriptif, yaitu memberikan gambaran atau pemaparan mengenai konsep tanggung jawab internasional dalam hukum internasional publik dan konsep tanggung jawab internasional dalam hukum ruang angkasa.

\section{Hasil Penelitian dan Pembahasan}

\section{International Liability}

Konsep tanggung jawab dalam hukum internasional dijabarkan melalui terminologi international responsibility dan international liability. Sebenarnya istilah responsibility dan liability, keduanya mengandung pengertian yang sama dengan konotasi yang berbeda. Pada awal perkembangannya, suatu tanggung jawab internasional terikat oleh adanya unsur pelanggaran terhadap kewajiban berdasarkan suatu ketentuan yang mengikat (internationally wrongful act). Dengan demikian, setiap tindakan negara yang internationally wrongful act akan menimbulkan tanggung jawab internasional dari negara yang bersangkutan. Konsep ini dikenal sebagai konsep tanggung jawab internasional dalam arti international responsibility. Pada perkembangan selanjutnya, dapat dikatakan bahwa suatu tanggung jawab internasional tidak hanya terikat oleh adanya tindakan dari suatu negara yang mengabaikan kewajiban-kewajibannya tetapi adanya unsur yang lain, yaitu unsur kerugian terhadap negara lain (damage). Konsep ini dikenal sebagai konsep tanggung jawab internasional dalam arti international liability. Berikut adalah perkembangan konsep tanggung jawab internasional dalam arti international liability. 


\section{Perkembangan Bases of Liability dalam Hukum Internasional}

Secara terminologi, istilah liability berasal dari kata Latin Ligare dan kata Perancis Lier yang berarti terikat/mengikat. ${ }^{8}$ Menurut Bin Cheng istilah liability seringkali digunakan untuk menunjuk pada kewajiban yang timbul sebagai konsekuensi dari suatu pelanggaran terhadap satu kewajiban hukum, yaitu kewajiban untuk melakukan upaya perbaikan terhadap segala kerugian yang disebabkannya, terutama dalam bentuk pembayaran sejumlah ganti rugi. ${ }^{9}$ Dengan demikian, secara umum istilah ini digunakan untuk menunjuk pada suatu kewajiban hukum untuk memperbaiki suatu kerusakan/kerugian tanpa mensyaratkan adanya suatu kesalahan, sehingga tanggung jawab internasional (international liability) untuk kerugian yang ditimbulkannya dapat merupakan tanggung jawab yang diasumsikan atau tanggung jawab yang dipaksakan. Pendapat ini diperkuat oleh Doo Hwan Kim yang menyatakan bahwa terhadap adanya suatu pelanggaran ketentuan hukum yang menyebabkan kerugian terhadap pihak lain, tanggung jawab hukum secara integral mengharuskan suatu kewajiban hukum bagi pelaku pelanggaran untuk memberikan ganti rugi kepada korban atas kerugian yang disebabkannya, sehingga pelaku pelanggaran dapat mengembalikan kondisi pada keadaan semula seperti sebelum terjadi pelanggaran. Dengan demikian pelaku pelanggaran menjadi bertanggung jawab (liable) untuk suatu kerugian. Selengkapnya Doo Hwan Kim menyatakan sebagai berikut: ${ }^{10}$

In the case of a breach of a legal rule causing damage to another, legal responsibility entails a legal obligation incumbent on the author of the breach to make integral reparation to the victims for the damage so caused in order to restore the position to what it probably would have been had the breach not taken place.

Menurut Bin Cheng, dalam hukum internasional, penerapan international liability untuk kasus-kasus tertentu dapat dipaksakan oleh hukum internasional umum atau perjanjian internasional atau diasumsikan oleh subyek-subyek hukum internasional. Intinya, tidak akan ada suatu tanggung jawab (liability) hukum tanpa

${ }^{8}$ Nathalie L.J.T. Horbach, sebagaimana dikutip oleh I.B.R. Supancana, "Tanggung Jawab Publik Negara Terhadap Kegiatan Keruangangkasaan”, Jurnal Hukum dan Dinamika Masyarakat, Vol.1, Nomor 2, April 2004, hlm. 2 .

${ }_{9}$ Bin Cheng, General Principles of Law as Applied by International Courts and Tribunals, Cambridge, Grotius, 1987, hlm.10.

${ }^{10}$ Doo Hwan Kim, "a Commentary to the Article VI of the OST", Proceedings on United Nations/Republic of Korea Workshop on Space Law, New York, 2004, hlm. 78. 
suatu kewajiban hukum yang telah ada sebelumnya, apakah kewajiban itu didasarkan pada konsep tanggung jawab untuk suatu internationally wrongful acts, atau dipaksakan oleh hukum internasional umum, atau diasumsikan oleh kesepakatan. Selengkapnya Bin Cheng menyatakan sebagai berikut:11

In reality, there can be no legal liability without a pre-existing legal obligation, whether the obligation is based on the concept of responsibility for an internationally wrongful acts, or imposed by general international law, or assumed by consent.

Liability sebagai suatu konsep hukum dirumuskan dengan mendasarkan kepada beberapa teori dan prinsip dasar hukum. Teori yang mendukung konsep liability internasional adalah theorie $d u$ risque cree, yaitu teori yang menyatakan bahwa barang siapa yang menciptakan suatu resiko harus menanggung konsekuensi dari adanya resiko tersebut. Teori ini banyak digunakan pada perkembangan awal pembentukan hukum tradisional negara-negara. ${ }^{12}$ Hukum tradisional negara-negara menggunakan liability sebagai suatu konsep untuk menjaga keharmonisan hubungan antara suku-suku bangsa (tribes) atau anggota masyarakat dalam suatu suku bangsa itu sendiri. ${ }^{13}$ Ketika terdapat pelanggaran terhadap hukum yang berlaku diantara mereka (hukum kebiasaan), maka pelaku pelanggaran harus bertanggungjawab untuk membayar sejumlah ganti kerugian. Pembayaran sejumlah ganti kerugian ini ditujukan baik untuk menjaga keharmonisan hubungan diantara masyarakat suku bangsa itu sendiri maupun untuk keharmonisan hubungan antara masyarakat suku bangsa itu dengan Tuhannya atau dengan alam.

Pada perkembangan selanjutnya karena pengaruh perkembangan 'moral philosophy' dari ajaran agama yang mengarah pada pengakuan kesalahan moral sebagai dasar yang tepat untuk perbuatan melawan hukum ${ }^{14}$, prinsip tanggung jawab berdasarkan kesalahan (liability based on fault) mulai banyak digunakan bahkan kemudian liability based on fault menjadi satu-satunya dasar tanggung jawab. Berdasarkan prinsip liability based on fault tanggung jawab tidak akan

${ }^{11}$ Bin Cheng, General Principles... Op. Cit., hlm. 170.

12 Ida Bagus Rahmadi Supancana menggunakan istilah "Tribes Law" untuk hukum tradisional negaranegara. Lihat Ida Bagus Rahmadi Supancana, The International Regulatory Regime Governing the Utilization of EarthOrbits, Disertasi, Leiden University, The Netherlands, 1998, hlm. 160.

${ }^{13}$ Ibid.

14 J.G. Fleming sebagaimana dikutip oleh E. Saefullah Wiradipradja, Tanggung Jawab Pengangkut Dalam Hukum Pengangkutan Udara Internasional dan Nasional, Penerbit Liberty, Yogyakarta, 1989, hlm. 69. 
pernah lahir tanpa adanya kesalahan (fault), sehingga fault menjadi satu-satunya faktor yang melahirkan tanggung jawab. Prinsip tanggung jawab berdasarkan kesalahan ini telah diimplementasikan pada hukum nasional di berbagai negara.

Di Indonesia prinsip liability based on fault antara lain terdapat dalam Pasal 1365 Kitab Undang-Undang Hukum Perdata (KUHPt) yang mengadopsi ketentuan Pasal 1382 Code Napoleon 1804 di Perancis dan Pasal 1401 Burgerlijk Wetboek di Belanda. ${ }^{15}$ Pasal 1365 KUHPt yang dikenal sebagai pasal perbuatan melawan hukum menetapkan unsur-unsur yang harus dipenuhi dalam suatu gugatan liability based on fault, yaitu: pertama, adanya perbuatan melawan hukum dari pihak tergugat; kedua, perbuatan tersebut dapat dipersalahkan kepadanya; dan ketiga, adanya kerugian yang diderita penggugat sebagai akibat dari kesalahan tersebut.

Hal yang sangat penting dalam prinsip liability based on fault adalah masalah beban pembuktian. Sebagai ketentuan umum, prinsip liability based on fault menetapkan penggugat (plaintiff) yang berkewajiban untuk membuktikan bahwa tergugat (defendant) telah melakukan perbuatan melawan hukum, telah melakukan suatu kesalahan, dan akibat kesalahannya itu mengakibatkan kerugian kepada pihak penggugat.

Pada perkembangan selanjutnya lahir prinsip liability yang lain, yaitu liability yang didasarkan kepada doktrin "res ipsa loquitur" (the thing speaks for itself). Berdasarkan doktrin the thing speaks for itself tanggung jawab dan pihak yang bertanggung jawab harus ditentukan sesuai dengan kondisi aktual dari suatu kasus. Berdasarkan doktrin ini pula lahir sistem pembuktian terbalik, yaitu pihak penggugat tidak layak dibebani kewajiban untuk membuktikan adanya kesalahan pada pihak tergugat, akan tetapi sebaliknya, pihak tergugatlah yang harus membuktikan bahwa kerugian yang timbul bukan disebabkan oleh kesalahannya. Sesuai dengan arti res ipsa loquitur ${ }^{16}$ itu sendiri, pihak penggugat cukup menunjukkan adanya kerugian atau kecelakaan untuk dapat menuntut pihak tergugat, dan bila pihak tergugat tidak dapat membuktikan bahwa

15 Pada tahun 1809 Code Napoleon dinyatakan berlaku di Belanda yang kemudian diubah menjadi Code Civil pada tahun 1911. Setelah memperoleh kemerdekaan dari Perancis, Belanda menyusun Burgerlijk Wetboek (B.W.) yang isinya sama dengan Code Civil dengan beberapa perkecualian. B.W. dinyatakan berlaku pada tahun 1838. Selengkapnya lihat E. Saefullah Wiradipradja, Tanggung Jawab Pengangkut... Op. Cit., hlm. 22.

${ }_{16}$ Res ipsa loquitur berarti the thing speaks for itself i.e. the situation or the fact speaks for itself. Lihat H. Drion sebagaimana dikutip oleh E. Saefullah Wiradipradja, Ibid., hlm. 78. 
kerugian tersebut bukan karena kesalahannya, maka dia harus membayar santunan atas kerugian tersebut.

Prinsip liability berdasarkan doktrin res ipsa loquitur telah diterapkan antara lain dalam hukum transportasi udara internasional yang dikenal dengan prinsip tanggung jawab atas dasar praduga (presumption of liability atau presumption of negligence or fault). Prinsip presumption of liability diterapkan dalam Konvensi Warsawa 192917 yang diberlakukan bagi transportasi udara internasional.18 Berdasarkan prinsip presumption of liability yang diterapkan dalam instrumen hukum transportasi udara tersebut, pengangkut bertanggung jawab atas kerugian yang timbul kecuali pengangkut dapat membuktikan pihaknya telah mengambil semua tindakan yang perlu (all necessary measures) untuk menghindarkan kerugian tersebut, atau bahwa hal tersebut tidak mungkin dilakukannya. ${ }^{19}$ Diterapkannya prinsip presumption of liability dalam kegiatan transportasi udara akan memudahkan mekanisme pertanggungjawaban karena akan lebih mudah bagi pengangkut untuk membuktikan bahwa pihaknya tidak bersalah daripada bagi korban untuk membuktikan bahwa kerugian tersebut disebabkan karena kesalahan pengangkut. Hal ini adalah logis, karena pengangkut, dengan sendirinya, lebih menguasai semua permasalahan transportasi udara dibanding dengan para penumpang atau pengirim dan penerima kargo. Alasan lain penerapan prinsip ini dalam kegiatan transportasi udara adalah untuk melindungi pengangkut udara, pada taraf permulaan perkembangannya, dari kehancuran sebagai akibat suatu kecelakaan yang besar. ${ }^{20}$

Selanjutnya berkembang prinsip tanggung jawab mutlak yang dalam kepustakaan dikenal dengan istilah strict liability atau absolute liability. Prinsip ini merupakan prinsip yang memandang adanya tanggung jawab tanpa keharusan untuk membuktikan adanya kesalahan. Dengan perkataan lain 'kesalahan' merupakan suatu yang tidak relevan untuk dipermasalahkan apakah pada

\footnotetext{
17 Nama lengkap konvensi ini adalah Convention for the Unification of Certain Rules Relating to Inernational Transportation by Air, 1929.

18 Lihat Article 17 untuk kerugian terhadap penumpang, Article 18 untuk kerugian terhadap bagasi dan kargo, dan Article 19 untuk kerugian akibat kelambatan (delay).

${ }^{19}$ Article 20 (1) Konvensi Warsawa 1929 menyatakan sebagai berikut:

The carrier shall not be liable if he proves that he and his agents have taken all necessary measures to avoid the damage or that it was impossible for him or them to take such measures.

${ }^{20}$ E. Saefullah Wiradipradja, Hukum Transportasi Udara: Dari Warsawa 1929 ke Montreal 1999, hlm. 83.
} 
kenyataannya ada atau tidak. ${ }^{21}$ Dengan demikian konsep tidak ada tanggung jawab tanpa adanya kesalahan mulai tergeser.

Penggunaan istilah strict liability atau absolute liability dalam kepustakaan sering tampak secara bergantian. Oleh karena itu, secara teoritis maupun praktis sulit mengadakan pembedaan yang tegas terhadap kedua istilah terebut. Namun beberapa ahli telah menunjukkan adanya perbedaan pokok antara kedua istilah tersebut. ${ }^{22}$ Bin Cheng, misalnya, berpendapat bahwa pada strict liability perbuatan yang menyebabkan kerugian harus dilakukan oleh orang yang bertanggung jawab. Hal ini berarti bahwa pada strict liability terdapat hubungan kausalitas antara pihak yang benar-benar bertanggung jawab dengan kerugian. Sedangkan pada absolute liability adanya hubungan kausalitas antara pihak yang bertanggung jawab dengan kerugian tidak disyaratkan. Dengan demikian absolute liability akan timbul pada saat keadaan yang menimbulkan tanggung jawab ada tanpa mempermasalahkan oleh siapa atau bagaimana terjadinya kerugian tersebut. Selanjutnya, Mircea Mateesco-Matte menjelaskan absolute liability sebagai prinsip tanggung jawab tanpa adanya kemungkinan untuk membebaskan diri. Sejalan dengan pendapat Matte, Ida Bagus Rahmadi Supancana menegaskan bahwa pada absolute liability tidak ada pembatasan dan pembebasan tanggung jawab, sedangkan pada strict liability pembatasan dan pembebasan tanggung jawab dapat diberlakukan. ${ }^{23}$

Merujuk kepada pendapat beberapa ahli tersebut, terdapat indikasi umum dalam membedakan kedua istilah tanggung jawab mutlak, yaitu pada strict liability pihak yang bertanggung jawab dapat membebaskan diri berdasarkan semua alasan yang sudah umum dikenal. Misalnya, act of God, contributory negligence, keadaan memaksa (force majeur) yang merupakan alasan-alasan umum pembebasan (conventional defences), atau karena keadaan perang, tindakan penguasa, dan sebagainya. Sedangkan pada absolute liability alasan-alasan umum

${ }^{21}$ E. Saefullah Wiradipradja, Tanggung Jawab Pengangkut... Op.Cit., hlm. 86.

22 Selengkapnya lihat pendapat Bin Cheng dan Mircea Matesco-Matte sebagaimana dikutip oleh E. Saefullah Wiradipradja, Ibid., hlm. 37.

${ }^{23}$ Ida Bagus Rahmadi Supancana, Op. Cit., hlm.162. Lihat juga Armel Kerrest, "Liability for Damage Caused by Space Activities" dalam Marietta Benko (Eds), Essential Air and Space Law 2: Current Problem and Perspectives for Future Regulation, Eleven International Publishing, The Netherlands, 2005, hlm. 96. 
pembebasan tersebut tidak berlaku kecuali secara khusus dinyatakan dalam instrumen-instrumen hukum tertentu.

Sejarahnya, prinsip tanggung jawab mutlak lahir pada akhir abad ke-19 ketika terjadi kasus Trail Smelter. ${ }^{24}$ Merujuk kepada kasus ini, walaupun tidak ditemukan ada unsur kesalahan tetapi salah satu pihak yang terlibat dalam kasus tersebut harus bertanggung jawab terhadap kerugian yang diakibatkan oleh kegiatannya. Pengadilan Arbitrase yang menangani kasus ini menetapkan, sebagai berikut: 25

Under the principle of international law...no state has the right to use or permit the use of territory in such a manner as to cause injury by fumes in or to the territory of another of the properties or persons therein, when the case is of serious consequence and the injury is established by clear and convincing evidence.

Pengadilan memutuskan bahwa Kanada harus mengganti kerugian atas tindakannya yang mencemari dan merusak sumber daya alam di wilayah Amerika Serikat. Pengadilan memerintahkan pula agar Kanada mengambil langkah-langkah yang perlu agar kasus seperti ini tidak terulang kembali.26

Putusan pengadilan arbitrase ini sebenarnya menguatkan prinsip tanggung jawab negara untuk tidak melakukan kegiatan yang dapat menyebabkan kerugian atau kerusakan lingkungan di wilayah negara lain atau di luar yurisdiksi wilayahnya. Tanggung jawab ini lahir karena adanya kewajiban negara-negara untuk menghormati hak-hak negara lain baik dalam keadaan damai maupun perang. Formulasi keputusan pengadilan arbitrasi terhadap kasus Trail Smelter ini oleh banyak ahli hukum telah diakui sebagai hukum kebiasaan internasional.

${ }^{24}$ Trail Smelter case adalah kasus pencemaran lingkungan lintas batas negara yang melibatkan Pemerintah Federal Kanada dan Amerika Serikat sebagai para pihak yang bersengketa pada tahun 1941. Kasus ini telah memberikan kontribusi terbangunnya Prinsip Pencemar Membayar (Polluter Pays Principle) dalam hukum lingkungan internasional. Secara singkat, sengketa terjadi karena asap pencemar dari sebuah pabrik peleburan bijih seng (zinc) yang berada di wilayah Kanada telah mencemari dan merusak tanah dan tanaman pangan di wilayah negara bagian Washington, Amerika Serikat. Asap yang dihasilkan dari pabrik peleburan tersebut mengandung gas sulfur dioksida yang terbawa angin sampai ke Lembah Sungai Columbia dan menyebabkan rusaknya tanaman pangan dan hutan di sekitar wilayah yang terlewati oleh asap tersebut sampai ke wilayah negara bagian Washington, Amerika Serikat. Berdasarkan hasil penyelidikan Departemen Pertanian Amerika Serikat, asap peleburan seng tersebut telah mengakibatkan terbakarnya daun-daun tanaman pangan dan juga mengakibatkan produktivitas tanah menurun. Hal ini secara tidak langsung akan menghambat pertumbuhan tanaman pangan dan menurunkan kualitas pangan.

${ }^{25}$ Lihat Trail Smelter Case (1941) sebagaimana dikutip oleh Philippe Sands, Principles of International Environmental Law I, Manchester University Press, 1994, hlm. 191. hlm. 302 .

${ }^{26}$ Huala Adolf, Aspek-Aspek Negara Dalam Hukum Internasional, PT Raja Grafindo Persada, Jakarta, 2002, 
Beberapa kasus dalam hukum internasional telah menerapkan prinsip ini, misalnya dalam kasus the Nuclear Test antara Australia melawan Perancis.

The Nuclear Test Case menunjuk kepada sengketa antara Pemerintah Australia dan Pemerintah Perancis berkenaan dengan kegiatan uji senjata nuklir di udara yang dilakukan oleh Pemerintah Perancis di Samudera Pasifik Selatan (the South Pacific Ocean). Gugatan diajukan ke Mahkamah Internasional oleh Pemerintah Australia pada tahun 1973. Pemerintah Australia meminta kegiatan uji senjata nuklir segera dihentikan oleh Pemerintah Perancis dan meminta jaminan kepada Pemerintah Perancis bahwa kegiatan tersebut akan benar-benar berakhir karena kegiatan tersebut bertentangan dengan ketentuan hukum internasional yang berlaku. Terhadap kasus ini hakim de Castro menyampaikan pendapatnya, sebagai berikut: 27

"If it is admitted as a general rule that there is a right to demand prohibition of the emission by neighbouring properties of noxious fumes, the consequences must be drawn, by an obvious analogy, that the Applicant is entitled to ask the Court to uphold its claim that France should put an end to the deposit of radio-active fall-out on its territory"

Pada prinsipnya, pada kasus the Nuclear Test, Mahkamah Internasional menegaskan bahwa negara-negara wajib untuk mencegah kerusakan atau kerugian yang diakibatkan oleh kegiatan-kegiatan yang dilakukan di dalam wilayahnya. ${ }^{28}$

Pada perkembangannya kegiatan-kegiatan yang berpotensi membahayakan lingkungan ini dikenal dengan istilah extra hazardous activities atau ultra hazardous activities. Sifat kegiatan yang extra/ultra hazardous inilah yang menjadi unsur diterapkannya prinsip tanggung jawab mutlak dalam arti strict liability maupun absolute liability. ${ }^{29}$ Sebagaimana telah dijelaskan sebelumnya, berdasarkan prinsip ini pihak yang menimbulkan kerugian akibat kegiatan yang dilakukannya akan bertanggung jawab tanpa harus dibuktikan adanya kesalahan atau tidak. Satusatunya hal yang harus dibuktikan oleh penuntut adalah adanya hubungan antara kegiatan yang dilakukan dengan kerugian yang timbul. ${ }^{30}$

27 Selengkapnya lihat the Nuclear Tests Case (1974). Eric Heinze dan MalgosiaFitzmaurice, Landmark Cases in Public International Law, Kluwer Law International, London, 1998, hlm. 600.

${ }^{28}$ Huala Adolf, Op. Cit.

${ }^{29}$ Ida Bagus Rahmadi Supancana, The International Regulatory Regime Governing the Utilization of Earth-Orbits, Disertasi, Leiden University, the Netherlands, 1998, hlm. 161.

${ }^{30}$ Ibid. 
Pengaruh Perkembangan Bases of Liability dalam Hukum Internasional terhadap Kegiatan Keruangangkasaan

Sebagaimana telah diuraikan sebelumnya Article VII the OST mengakui bahwa negara merupakan aktor utama dalam kegiatan keruangangkasaan dan negaralah yang bertanggungjawab secara internasional untuk kegiatan keruangangkasaan nasionalnya, baik yang dilakukan oleh badan pemerintah maupun oleh entitas non-pemerintah. Article VII the OST ini lebih lanjut dijabarkan dalam Liability Convention 1972, yang menyebut negara yang memiliki kategori berdasarkan Article VII the OST sebagai 'Launching State' atau negara peluncur. ${ }^{31}$

Berdasarkan Article II Liability Convention 1972, suatu negara peluncur secara absolut bertanggung jawab untuk membayar sejumlah ganti rugi atas kerugian yang disebabkan oleh obyek ruang angkasanya yang terjadi di permukaan bumi atau terhadap pesawat udara yang sedang dalam penerbangan. Selengkapnya Article II Liability Convention 1972 menetapkan sebagai berikut: A launching State shall be absolutely liable to pay compensation for damage caused by its space object on the surface of the Earth or to aircraft in flight.

Article selanjutnya menetapkan bahwa dalam hal kerugian terhadap obyek ruang angkasa suatu negara peluncur yang disebabkan oleh obyek ruang angkasa suatu negara peluncur lainnya yang terjadi di luar permukaan bumi atau di luar badan pesawat udara yang sedang dalam penerbangan, berlaku prinsip tanggung jawab berdasarkan kesalahan (based on fault liability). ${ }^{32}$ Namun, terhadap kerugian yang diderita oleh warga negara dari negara peluncur atau warga negara asing yang terlibat dalam kegiatan peluncuran, ketentuan dalam Liability Convention 1972 tidak dapat diterapkan. ${ }^{33}$ Terhadap pihak-pihak ini akan berlaku hukum nasional negara-negara yang terkait dengan kegiatan peluncuran.

Mengingat kriteria negara peluncur berdasarkan Liability Convention 1972 adalah negara yang melakukan atau menyelenggarakan peluncuran atau negara yang menyediakan wilayahnya dan juga memfasilitasi peluncuran obyek ruang angkasa, maka konsep tanggung jawab negara dalam hukum ruang angkasa

\footnotetext{
${ }^{31}$ Lihat Article I (c) Liability Convention 1972.

${ }^{32}$ Lihat Article III Liability Convention 1972.

${ }^{33}$ Selengkapnya lihat Article VII Liability Convention 1972
} 
tidak mempermasalahkan apakah obyek ruang angkasa itu dimiliki dan dioperasikan oleh suatu negara atau oleh suatu entitas non-pemerintah, tetapi lebih berhubungan dengan kegiatan peluncuran itu sendiri. Oleh karena itu, bases of liability yang digunakan dalam Liability Convention 1972 disesuaikan dengan karakteristik kegiatan keruangangkasaan yang dilakukan.

Berdasarkan Article II Liability Convention 1972 tanggung jawab absolute berlaku apabila kerugian yang disebabkan oleh obyek ruang angkasa dari negara peluncur terjadi di atas permukaan bumi atau didalam pesawat udara yang sedang melakukan penerbangan. Merujuk kepada rezim tanggung jawab mutlak dalam hukum internasional, maka istilah absolute menunjuk kepada dua hal. Pertama, bahwa tanggung jawab tersebut bersifat objective, yaitu tanpa adanya unsur kesalahan (without fault) dan kedua, menunjukkan tidak ada indikasi pembebasan dari tanggung jawab sebagaimana yang terdapat pada strict liability. Pada strict liability pihak yang bertanggung jawab dapat membebaskan diri berdasarkan semua alasan yang sudah umum dikenal. Misalnya, act of God, contributory negligence, keadaan memaksa (force majeur) yang merupakan alasanalasan umum pembebasan (conventional defences), atau karena keadaan perang, tindakan penguasa, dan sebagainya. Sedangkan pada absolute liability alasanalasan umum pembebasan tersebut tidak berlaku kecuali secara khusus dinyatakan dalam instrumen-instrumen hukum tertentu. Oleh karena dinyatakan secara khusus dalam Liability Convention 1972, maka suatu negara peluncur dapat membebaskan diri dari tanggung jawab yang bersifat absolute apabila kerugian yang terjadi merupakan akibat dari kesalahan serius (gross negligence) atau tindakan yang disengaja oleh pihak yang dirugikan. Alasan pembebasan tanggung jawab ini dinyatakan secara khusus dalam Article VI dari Liability Convention 1972, sebagai berikut: ${ }^{34}$

Subject to the provisions of paragraph 2 of this article, exoneration from absolute liability shall be granted to the extent that a launching State establishes that the damage has resulted either wholly or partially from gross negligence or from an act or omission done with intent to cause damage on the part of a claimant State or of natural or juridical persons it represents. 
Terlepas dari adanya kekhususan yang dinyatakan dalam Liability Convention 1972 tersebut di atas, penerapan prinsip tanggung jawab mutlak dalam arti absolute liability dalam kegiatan keruangangkasaan, pada dasarnya mendapat pengaruh dari perkembangan bases of liability dalam hukum internasional. Sebagaimana yang berkembang pada hukum lingkungan internasional dan hukum transportasi udara internasional, yang menjadi pertimbangan rasional diterapkannya prinsip tanggung jawab tersebut adalah karena kegiatan keruangangkasaan termasuk kategori kegiatan yang berbahaya (dangerous activity). Sifat kegiatan yang extra/ultra hazardous inilah yang menjadi unsur diterapkannya prinsip tanggung jawab mutlak dalam arti strict liability maupun absolute liability.

Selanjutnya berdasarkan Article III Liability Convention 1972, untuk kerugian yang menimpa obyek ruang angkasa suatu negara peluncur yang disebabkan oleh obyek ruang angkasa suatu negara peluncur lainnya yang terjadi di luar permukaan bumi atau di luar badan pesawat udara yang sedang dalam penerbangan, berlaku prinsip tanggung jawab berdasarkan kesalahan (based on fault liability). Berdasarkan prinsip liability based on fault tanggung jawab tidak akan pernah lahir tanpa adanya kesalahan (fault), sehingga fault menjadi satusatunya faktor yang melahirkan tanggung jawab. Merujuk pada perkembangan bases of liability dalam hukum internasional, sebenarnya terdapat konsep tanggung jawab yang berbeda antara liability based on fault dengan liability without fault. Keduanya memiliki konsep yang berlawanan terutama dalam hubungannya dengan pembagian beban pembuktian.

Sebagai ketentuan umum, prinsip liability based on fault menetapkan penggugat (plaintiff) yang berkewajiban untuk membuktikan bahwa tergugat (defendant) telah melakukan perbuatan melawan hukum, telah melakukan suatu kesalahan, dan akibat kesalahannya itu mengakibatkan kerugian kepada pihak penggugat. Sedangkan dalam prinsip liability without fault (baca: absolute liability) pihak penggugat tidak perlu membuktikan ada atau tidak adanya kesalahan dari pihak tergugat. Dalam konteks kegiatan keruangangkasaan yang dikategorikan sebagai kegiatan yang sangat membahayakan (extra/ultra hazardous activities), maka berdasarkan Article II Liability Convention 1972, pihak ketiga yang sama sekali tidak 
terlibat dalam kegiatan keruangangkasaan harus dilindungi secara memadai. Oleh karena itu, prinsip tanggung jawab yang absolute menjadi sangat relevan untuk diterapkan. Sebaliknya, untuk kerugian yang menimpa obyek ruang angkasa suatu negara peluncur yang disebabkan oleh obyek ruang angkasa suatu negara peluncur lainnya yang terjadi di luar permukaan bumi atau di luar badan pesawat udara yang sedang dalam penerbangan, para pihak dianggap memiliki posisi yang sederajat, sehingga prinsip tanggung jawab based on fault yang diterapkan berdasarkan Article III Liability Convention dapat menjadi suatu penyelesaian yang masuk akal.

\section{Pembentukan Sistem Tanggung Jawab dalam Kegiatan Keruangangkasaan di Indonesia}

Sebagaimana telah dijelaskan sebelumnya, hasil kajian mengenai perkembangan bases of liability dalam hukum internasional dan bagaimana implikasinya terhadap kegiatan keruangangkasaan akan dijadikan bahan analisis untuk membangun sistem tanggung jawab dalam kegiatan keruangangkasaan di Indonesia. Hasil kajian ini juga akan sangat diperlukan dalam upaya penyusunan regulasi nasional yang mangatur kegiatan keruangangkasaan di Indonesia mengingat Indonesia sampai saat ini belum memiliki peraturan perundangundangan nasional yang mengatur tanggung jawab negara dalam kegiatan keruangangkasaan baik dalam arti responsibility maupun liability, padahal Indonesia sudah melakukan kegiatan keruangangkasaan sejak tahun 1976.35

Pada tanggal 27 Februari 1996 Indonesia secara resmi telah menjadi peserta Liability Convention 1972 melalui Keputusan Presiden RI Nomor 20 Tahun 1996. Enam tahun kemudian tepatnya tanggal 17 April 2002 Pemerintah Republik Indonesia mengaksesi Space Treaty 1967 melalui Undang-Undang Nomor 16 Tahun 2002. Selain menjadi negara peserta Liability Convention 1972, Indonesia

35 Indonesia telah melakukan aktivitas di ruang angkasa sejak tahun 1976 yaitu peluncuran seri Satelit Komunikasi PALAPA. Pada waktu itu, sebagian besar satelit milik Indonesia diluncurkan menggunakan jasa peluncuran Badan Ruang Angkasa Amerika Serikat (National Aeronautics and Space Administration/NASA) dan tempat peluncurannya juga di wilayah Amerika Serikat. Peluncuran satelit milik Indonesia relatif sukses, kecuali peluncuran satelit PALAPA B2 pada tahun 1984 yang gagal menempati posisi orbit yang dituju sehingga satelit tersebut hilang dari pusat kendali. Meskipun demikian, kegagalan peluncuran ini tidak menyebabkan kerugian bagi pihak ketiga di bumi baik kerusakan lingkungan ataupun kerugian jiwa. Bahkan pada akhirnya satelit tersebut dapat ditemukan kembali oleh NASA dan kemudian dijual kembali kepada pihak Indonesia dan berhasil diluncurkan kembali pada tahun 1990 dengan nama PALAPA B2R. 
juga telah resmi menjadi peserta dua konvensi lainnya, yaitu Convention on Registration of Object Launched into Outer Spaces, 1975 (Registration Convention 1975) yang telah disahkan melalui Keputusan Presiden Nomor 5 Tahun 1997 (Lembaran Negara Republik Indonesia Tahun 1997 Nomor 12) dan Agreement on Rescue of Astronauts, the Return of Astronauts, and the Return of Objects Launched into Outer Space, 1968 (Rescue Agreement 1968) yang telah disahkan melalui Keputusan Presiden Nomor 4 Tahun 1999 tentang Pengesahan (Lembaran Negara Republik Indonesia Tahun 1999 Nomor 5).

Kebijakan mengaksesi instrumen-instrumen hukum internasional tersebut, selain telah memberikan manfaat bagi negara Republik Indonesia, juga menimbulkan kewajiban internasional bagi Indonesia sebagai negara yang ikut serta dalam kegiatan di ruang angkasa. Dalam rangka melaksanakan ketentuanketentuan hukum ruang angkasa internasional tersebut, khususnya the Outer Space Treaty 1967, pada tanggal 9 Juli 2013 Rapat Paripurna DPR RI menyepakati dengan suara bulat untuk mengesahkan Rancangan Undang-Undang tentang Keantariksaan menjadi Undang-Undang tentang Keantariksaan. Undangundang ini disahkan dan diundangkan di Jakarta pada tanggal 6 Agustus 2013 dengan nama lengkap: Undang-Undang Republik Indonesia Nomor 21 Tahun 2013 tentang Keantariksaan (selanjutnya disebut sebagai UU tentang Keantariksaan).

Secara keseluruhan substansi pengaturan dalam UU tentang Keantariksaan meliputi materi-materi tentang kegiatan keruangangkasaan, termasuk mengenai tanggung jawab dan ganti rugi. ${ }^{36}$ Ketentuan mengenai tanggung jawab dalam kegiatan keruangangkasaan, secara umum diatur dalam beberapa pasal, yaitu Pasal 76 sampai dengan Pasal $78 .{ }^{37}$ UU tentang Keantariksaan selanjutnya

${ }^{36}$ Ruang lingkup materi yang diatur dalam UU tentang Keantariksaan, selengkapnya lihat Pasal 6 UU tentang Keantariksaan.

37 Pasal 76: (1) Pemerintah Republik Indonesia bertanggung jawab secara internasional atas setiap Penyelenggaraan Keantariksaan yang dilakukan di wilayah kedaulatan dan/atau wilayah yurisdiksi Negara Kesatuan Republik Indonesia; (2) Dalam hal terdapat Kerugian akibat dari Penyelenggaraan Keantariksaan, ganti rugi menjadi tanggung jawab Penyelenggara Keantariksaan. (3) Tanggung jawab sebagaimana dimaksud pada ayat (1) dilakukan sesuai dengan ketentuan peraturan perundang-undangan. Pasal 77: (1) Tanggung jawab terhadap Kerugian yang ditimbulkan oleh Penyelenggaraan Keantariksaan yang terjadi di permukaan bumi atau pada pesawat udara yang sedang dalam penerbangan bersifat mutlak. (2) Tanggung jawab terhadap Kerugian yang terjadi di Antariksa dan/atau terhadap Wahana Antariksa di antara sesama Penyelenggara Keantariksaan didasarkan atas adanya unsur kesalahan. (3) Tanggung jawab terhadap Kerugian di antara sesama Penyelenggara Keantariksaan sebagaimana dimaksud pada ayat (2) ditetapkan berdasarkan perjanjian para pihak. Pasal 78: (1) 
menetapkan bahwa setiap penyelenggara kegiatan keruangangkasaan wajib mengganti setiap kerugian yang timbul akibat penyelenggaraan kegiatan keruangangkasaan yang dilakukan. Tuntutan ganti rugi dapat dilakukan sesuai dengan mekanisme hukum internasional yang berlaku, baik melalui jalur diplomatik, melalui Komisi Penuntutan, maupun melalui badan peradilan nasional dan bentuk kerugian sebagai akibat dari kegiatan Keantariksaan yang dapat dimintakan kompensasinya adalah kerugian yang bersifat fisik dan langsung, termasuk biaya-biaya yang dikeluarkan untuk melakukan kegiatan pertolongan dan pembersihan. ${ }^{38}$ Kemudian, terhadap tanggung jawab atas kerugian di antara sesama penyelenggara keantariksaan sebagaimana diatur dalam Pasal 77(3), UU tentang Keantariksaan menetapkan bahwa beban tanggung jawab renteng atas kerugian yang diderita oleh negara atau pihak asing ditentukan oleh penyelenggara keantariksaan terkait. ${ }^{39}$

UU tentang Keantariksaan juga telah mengatur mengenai prosedur penuntutan ganti rugi. Berdasarkan Pasal 82 UU tentang Keantariksaan, dalam hal terjadi kerugian yang diderita oleh badan dan/atau warga negara Indonesia akibat kegiatan keruangangkasaan, gugatan dapat diajukan kepada pihak pelaku kegiatan melalui lembaga peradilan, lembaga arbitrase, dan/atau lembaga alternatif penyelesaian sengketa. Pengajuan gugatan dan penyelesaian ganti rugi tersebut dapat difasilitasi oleh Pemerintah dan pembayaran ganti rugi kepada korban harus dilaksanakan dengan segera, efektif, dan layak.40 Ketentuan mengenai ganti rugi dalam UU tentang Keantariksaan tidak menetapkan mengenai pembatasan ganti rugi. Namun, UU ini telah memerintahkan pembentukan peraturan pelaksananya. ${ }^{41}$ Selanjutnya, untuk mengantisipasi pemenuhan ganti kerugian oleh penyelenggara kegiatan keruangangkasaan, UU tentang Keantariksaan telah merumuskan pasalpasal mengenai asuransi dan penjaminan. ${ }^{42}$

Dalam hal terjadi pengalihan kepemilikan terhadap aset Keantariksaan, tanggung jawab Penyelenggara Keantariksaan beralih sejak berlakunya perjanjian pengalihan. (2) Pengalihan kepemilikan aset Keantariksaan milik pemerintah dilakukan sesuai dengan peraturan perundang-undangan yang mengatur barang milik negara/daerah. (3) Perjanjian pengalihan sebagaimana dimaksud pada ayat (1) tidak dapat meniadakan ketentuan yang terdapat dalam Bab VI.

${ }^{38}$ Ketentuan mengenai ganti rugi selengkapnya lihat Pasal 79 dan 80 UU tentang Keantariksaan.

${ }^{39}$ Lihat Pasal 81 UU tentang Keantariksaan.

40 Selengkapnya lihat Pasal 82 UU tentang Keantariksaan.

${ }^{41}$ Pasal 83 UU tentang Keantariksaan.

${ }^{42}$ Lihat Pasal 84 UU tentang Keantariksaan 
Ketentuan dalam pasal-pasal tersebut di atas pada dasarnya belum merumuskan secara jelas tentang sistem tanggung jawab yang dianut oleh Indonesia dalam kegiatan keruangangkasaan. Ketentuan mengenai tanggung jawab dan ganti rugi sebagaimana diatur dalam Pasal 76 sampai dengan Pasal 83 UU tentang Keantariksaan hanya menjelaskan prinsip umum tentang tanggung jawab dalam hukum ruang angkasa yang pada intinya menetapkan bahwa Pemerintah Republik Indonesia bertanggung jawab secara internasional atas setiap penyelenggaraan kegiatan keruangangkasaan yang dilakukan di wilayah kedaulatan dan/atau wilayah yurisdiksi Negara Kesatuan Republik Indonesia. Selanjutnya, apabila terdapat kerugian akibat dari penyelenggaraan kegiatan keruangangkasaan, ganti rugi menjadi tanggung jawab penyelenggara kegiatan. Penjabaran sistem tanggung jawab tersebut selanjutnya akan diatur dalam peraturan pelaksanaan (Peraturan Pemerintah). 43

Sampai saat ini di Indonesia belum terbentuk peraturan pelaksanaan yang menjabarkan sistem tanggung jawab dalam kegiatan keruangangkasaan. Oleh karena itu, hasil kajian mengenai perkembangan bases of liability dalam hukum internasional dan bagaimana implikasinya terhadap kegiatan keruangangkasaan akan dijadikan bahan analisis untuk membangun sistem tanggung jawab dalam kegiatan keruangangkasaan di Indonesia. Dengan demikian, bases of liability yang ditetapkan dalam Article II dan Article III Liability Convention 1972 semestinya menjadi salah satu objek pengaturan dan dapat diaplikasikan dalam legislasi nasional tentang tanggung jawab dalam kegiatan keruangangkasaan di Indonesia.

\section{Penutup}

Berdasarkan paparan analisis di atas, penelitian ini menyimpulkan: pertama, berdasarkan sejarah perkembangannya, dalam hukum internasional berlaku tiga bases of liability yang masing-masing memiliki karakter dan mekanisme penerapan yang berbeda. Kedua, implikasi penting dari perkembangan bases of liability dalam hukum internasional ini tersurat dalam

${ }^{43}$ Lihat Pasal 83 UU tentang Keantariksaan. 
Article II dan Article III Liability Convention 1972 yang merupakan elaborasi dari ketentuan Article VII the OST. Selanjutnya, sebagai konsekuensi dari keikutsertaan Indonesia dalam instrumen-instrumen hukum ruang angkasa internasional, bases of liability yang ditetapkan dalam Article II dan Article III Liability Convention 1972 semestinya dapat diaplikasikan dalam legislasi nasional tentang tanggung jawab dalam kegiatan keruangangkasaan di Indonesia.

\section{Daftar Pustaka}

Adolf, Huala, Aspek-Aspek Negara Dalam Hukum Internasional, Jakarta: PT Raja Grafindo Persada, 2002.

Amirudin dan Zainal Asikin, Pengantar Metode Penelitian Hukum, Rajawali Press, Jakarta, 2010.

Bagus Rahmadi Supancana, Ida, The International Regulatory Regime Governing the Utilization of Earth-Orbits, Disertasi, Leiden University, The Netherlands, 1998.

Benko, Marietta (Eds), Essential Air and Space Law 2: Current Problems and Perspectives for Future Regulation, Eleven International Publishing, 2005.

Cheng, Bin, General Principles of Law as Applied by International Courts and Tribunals, Grotius, Cambridge, 1987.

Fajar, Mukti dan Yulianto Achmad, Dualisme Penelitian Hukum Normatif dan Empiris, Pustaka Pelajar, Yogyakarta, 2010.

Hanitijo Soemitro, Ronny, Metodologi Penelitian Hukum dan Jurimetri, Ghalia Indonesia, 1990.

Kim, Doo Hwan, "a Commentary to the Article VI of the OST", Proceedings on United Nations/Republic of Korea Workshop on Space Law, New York, 2004.

Sands, Philippe, Principles of International Environmental Law I, Manchester University Press, 1994.

Soekanto, Soerjono, Pengantar Penelitian Hukum, UI-Press, 2008.

Supancana, I.B.R., “Tanggung Jawab Publik Negara Terhadap Kegiatan Keruangangkasaan", Jurnal Hukum dan Dinamika Masyarakat, Vol.1, Nomor 2, April 2004.

Wiradipradja, E Saefullah, Tanggung Jawab Pengangkut Dalam Hukum Pengangkutan Udara Internasional dan Nasional, Liberty, Yogyakarta, 1989.

---------, Hukum Transportasi Udara: Dari Warsawa 1929 ke Montreal 1999, Kiblat Buku Utama, Bandung, 2008. 
The United Nations General Assembly Resolution 1962 (XVIII) of 13 December 1963 on Principles Governing the Activities of States in the Exploration and Use of Outer Space.

Declaration of Legal Principles Governing the Activities of States in the Exploration and Use of Outer Space.

Treaty on Principles Governing the Activities of States in the Exploration and Use of Outer Space, including the Moon and Other Celestial Bodies, 1967 (the Outer Space Treaty/the OST).

Convention on International Liability for Damage Caused by Space Objects, 1972 (the Liability Convention).

Agreement between the Government of the Republic of Indonesia and the Government of the Russian Federation on Cooperation in the Field of the Exploration and Use of the Outer Space for Peaceful Purposes.

U.N. Charter, Article 13 (a), General assembly Resolution 174 (II), 21 November 1947.

Convention for the Unification of Certain Rules Relating to Inernational Transportation by Air, 1929 (Konvensi Warsawa 1929). 